\title{
Expression of p53 and PTEN in human primary endometrial carcinomas: Clinicopathological and immunohistochemical analysis and study of their concomitant expression
}

\author{
AGGELIS STAVROPOULOS ${ }^{1}$, MICHAIL VARRAS ${ }^{2}$, THIVI VASILAKAKI ${ }^{3}$, \\ VIKTORIA-KONSTANTINA VARRA ${ }^{4}$, AIKATERINI TSAVARI ${ }^{3}$, FANI-NIKI VARRA ${ }^{5}$, \\ APHRODITE NONNI $^{6}$, NIKOLAOS KAVANTZAS ${ }^{6}$ and ANDREAS C. LAZARIS ${ }^{6}$ \\ ${ }^{1}$ Fourth Obstetrics and Gynecology Department; ${ }^{2}$ Fifth Obstetrics and Gynecology Department, \\ 'Elena Venizelou' General Hospital, Athens 11521; ${ }^{3}$ Pathology Department, 'Tzaneio' General Hospital, Piraeus 18536; \\ ${ }^{4}$ Pharmacy Department, University of Patras, Patra 26504, Greece; ${ }^{5}$ Pharmacy Department, Frederick University, \\ Nicosia 1036, Republic of Cyprus; ${ }^{6}$ First Pathology Department, Medical School, \\ National Kapodistrian University, Athens 11527, Greece
}

Received July 24, 2018; Accepted February 4, 2019

DOI: $10.3892 / 01.2019 .10093$

\begin{abstract}
Endometrial carcinoma is a common malignancy of the female genital tract. Alterations in the expression levels of various oncogenes and tumor suppressor genes serve important roles in the carcinogenesis and biological behavior of endometrial carcinoma. The aim of the present study was to evaluate the combination and individual expression of p53 and phosphatase and tensin homolog (PTEN) protein in human endometrial carcinoma. In addition, the correlation of these proteins with clinicopathological parameters was also assessed. Retrospective immunohistochemical analysis of the expression of p53 and PTEN tumor suppressor proteins was conducted in 99 women with endometrial carcinoma. The overall rate of p53 and PTEN positivity was 89 and $77 \%$, respectively, according to the sum of stain intensity and scores of immunopositive cells. The sum of p53 positivity correlated strongly with PTEN expression $(\rho=0.256 ; \mathrm{P}=0.044)$. The concomitant sum of p53 and PTEN expression was identified in $45 \%$ of patients with endometrial adenocarcinoma. Notably, the sum of the immunohistochemical expression of p53 was significantly correlated with patient age $(\mathrm{P}=0.037)$, histologic type $(\mathrm{P}=0.008)$, histologic grade $(\mathrm{P}=0.002)$ and fallopian and/or ovarian invasion $(\mathrm{P}=0.014)$. Furthermore, PTEN expression was associated with myometrial invasion $(\rho=-0.377 ; P=0.002)$ and clinical stage $(P=0.019)$. In addition, concomitant p53 and PTEN expression was correlated with
\end{abstract}

Correspondence to: Dr Michail Varras, Fifth Obstetrics and Gynecology Department, 'Elena Venizelou' General Hospital, Plateia Elenas Venizelou 2, Ampelokipoi, Athens 11521, Greece E-mail: mnvarras@otenet.gr

Key words: p53, phosphatase and tensin homolog, endometrial, carcinoma, immunohistochemistry, expression, concomitant patient age $(\mathrm{P}=0.008)$ and histologic differentiation $(\mathrm{P}=0.028)$. The findings indicated a correlation between the expression of p53 and PTEN in endometrial adenocarcinoma, which suggested an intrinsic association between expression levels of these tumor suppressor genes. The study also suggested that concomitant p53 and PTEN expression contributed in characterizing the tumor behavior of endometrial carcinoma. Taken together, the present study suggested the combined expression of p53 and PTEN in the development of high-grade endometrial carcinoma in older patients. In addition, the findings indicated activation of different molecular pathways in the tumor progression between low-grade and high-grade endometrial carcinomas.

\section{Introduction}

Endometrial carcinoma is the most common invasive neoplasm of the female genital tract in the Western world, with a rising incidence. Furthermore, endometrial carcinoma is a significant contributor to gynecological mortality and the fourth most common cancer in women after breast, colon and lung cancer. Endometrial carcinoma primarily affects perimenopausal and postmenopausal women at a median age of diagnosis of 60 years old. Likely risk factors for this disease include diabetes, thyroid disease, hypertension, postmenopausal status, nulliparity, increased obesity, polycystic ovarian syndrome, early menarche and late menopause, radiation exposure, long-term use of unopposed exogenous estrogenic stimulation, a personal history of endometrial hyperplasia or breast cancer, and a family history of endometrial cancer (1-7).

Endometrial carcinoma is classified into two clinicopathological types (type I and type II). Type I endometrial carcinoma is the most common subtype, accounting for $>80 \%$ of endometrial tumors, and typically has a favorable prognosis. They are usually low-grade, well-differentiated endometrioid adenocarcinomas. These tumors are pathogenetically linked to an excess of unopposed estrogen, arise from endometrial 
hyperplasia and have hormone-receptor positivity. However, type II endometrial carcinoma is a less common type of serous or clear cell adenocarcinoma, accounting for only $\sim 10 \%$ of endometrial tumors. They are poorly differentiated, estrogen-independent tumors, which are associated with atrophic endometrium and have poorer outcomes $(8,9)$. Endometrial carcinoma is believed to arise from a variety of genetic alterations involving signaling pathways, activation of proto-oncogenes and inactivation of tumor suppressor genes. The development and progression of each group of endometrial carcinoma follows distinct molecular mechanisms of oncogenesis, reflecting the presence of type-specific genetic alterations. Although there are well-established surgical, radio- and chemotherapeutic treatments, the identification and characterization of biomarkers is necessary for improving the understanding of molecular pathways of the disease and for the development of specific novel molecular targeted therapies, with the aim to achieve greater specificity in tumor progression and metastatic processes, and to accurately evaluate the prognosis, particularly for recurrent and unfavorable disease course $(3,5,10,11)$.

Phosphatase and tensin homolog (PTEN) was identified in 1997, and is a tumor suppressor gene located on chromosome 10 (10q23) that suppresses cell proliferation and differentiation and is involved in the insulin signaling pathway. The protein encoded by this gene is a $55-\mathrm{kDa}$ protein composed of 403 amino acids, which has protein tyrosine phosphatase activities. PTEN protein negatively regulates the phosphatidylinositol 3-kinase (PI3K) signaling pathway. A downstream effector that emanates from PI3K is the Akt protein, which is a serine-threonine kinase. Therefore, PTEN protein can act through the Akt signaling pathway (12-14). PTEN protein under normal physiological conditions has an antagonistic effect on intracellular signaling pathways induced by integrin or growth factors. Furthermore, PTEN protein inhibits intracellular signaling, cell proliferation, cell migration and cellular adhesion formation. PTEN protein can also induce apoptosis in damaged cells $(15,16)$. Notably, PTEN protein lowers the levels of phosphatidylinositol-3,4,5-triphosphate (PIP3) in cells and down regulates cell proliferation by dephosphorylating the 3-position of PIP3, a second messenger of PI3K (14,16-18). In addition, PTEN is a proapoptotic molecule. Overexpression of wild-type PTEN is associated with increased expression of p27, which leads to suppression of cell growth through arrest of the cell cycle in $\mathrm{G}_{1}$. Previous findings indicated that wild-type PTEN restricts murine double minute $2(\mathrm{mdm} 2)$ to the cytoplasm and promotes p53 function (19,20). However, lack of functional PTEN protein contributes to tumorigenesis by preventing apoptosis and increasing growth and proliferative activity. In addition, loss of PTEN protein function leads to increased activity of mammalian target of rapamycin (mTOR) kinase, which is major downstream effector of Akt. Activation of the mTOR signaling pathway modulates angiogenesis, protein translation, growth and survival signals in neoplastic cells $(21,22)$. PTEN loss occurs through inactivation of the two alleles of PTEN via mutations or deletions, promoter hypermethylation, loss of heterozygosity without mutation, aberrant expression of regulatory microRNA and protein degradation $(18,23,24)$. The majority of mutations of the PTEN gene in tumors are localized in the phosphatase domain, which influences phosphatase activity (16). Decreased expression of PTEN gene has been indicated in various types of human cancer, including glioblastoma, melanoma, prostate cancer, breast cancer, lung cancer, ovary cancer and endometrial cancer (25). Furthermore, previous studies have revealed that PTEN expression is decreased in endometrial hyperplasia and in endometrial carcinoma compared to proliferative endometrium $(14,26,27)$.

Proapoptotic gene p53 is a tumor suppressor gene, which is located in 17p13.1 and expresses a nuclear 53-kDa phosphoprotein called $\mathrm{p} 53$. The $\mathrm{p} 53$ protein is a transcription factor that induces the expression of genes necessary for cell cycle arrest at the $G_{1}$ checkpoint and promotes the repair of damaged DNA. Additionally, the p53 protein initiates apoptosis (programmed cell death) in case of failed DNA repair (17). The p53 content of cells is maintained at low levels as the protein $\mathrm{mdm} 2$ binds with wild-type p53 protein and inhibits p53 transcriptional activity. The protein mdm 2 acts as a negative regulator of $\mathrm{p} 53$. This $\mathrm{p} 53-\mathrm{mdm} 2$ feedback loop is vital for cell-cycle regulation (28). Mutant forms of p53 are stable and accumulate to high levels intracellularly due to inability of the p53 mutant protein to optimally transactivate its negative regulator, mdm2 (28). Mdm2 also serves an oncogene role independent of p53. Notably, mdm 2 overexpression leads to excessive cell proliferation and promotes tumor formation (29). Inactivation of p53 protein provides the neoplastic cells with a higher capacity for division and proliferation, and therefore contributes to malignant change and tumor formation $(17,30)$. Inactivation of $\mathrm{p} 53$ protein may occur through mutation of the p53 gene, allelic loss, expansion of its negative regulators or complex formation with other nuclear proteins that are involved in p53-mediated signaling (28). Mutations in the p53 gene can induce changes of the protein conformation and may alter the tumor suppressive function (31). It has been indicated that the PI3K-Akt signaling pathway can be deregulated by inactivation of PTEN or activation of p53, resulting in malignant transformation (32). Notably, wild-type p53 is rapidly degraded and is rarely detectable with immunohistochemistry. Mutant p53 proteins are not degraded and accumulate in the nucleus. The immunohistochemical expression of p53 in the majority of endometrial carcinoma cases results from p53 alterations or functional changes. Furthermore, complete absence of p53 protein can be result from some missense mutations (33-35). In addition, overexpression of $\mathrm{p} 53$ protein has been associated with endometrioid carcinoma without gene alterations. Previous findings have indicated that the overexpression of p53 protein is associated with the formation of highly stable protein complexes by the binding of p53 to other overexpressed nuclear proteins, for example mdm-2 protein (36-38). In non-endometrioid endometrial carcinoma, p53 gene mutation and the loss of p53 function are the more common genetic alterations (39-41). Notably, mutational analysis is the gold standard examination for determining p53 status (35).

The purpose of the present study was to investigate the distribution of tumor suppressor genes p53 and PTEN in primary endometrial carcinoma specimens acquired from Greek patients. In addition, the associations of p53 and PTEN as separate factors with well-established clinicopathological prognostic factors, including patient age, histologic type, 
clinical stage, histologic grade, depth of myometrial invasion, lymph-vascular space invasion, presence of tumor necrosis and fallopian tube and/or ovarian invasion, were analyzed in order to understand the mechanism of endometrial carcinogenesis and clarify their prognostic significance. This was performed because results in the literature regarding this matter are contradictory (42). Also, the aim of the present study was to analyze the combination of p53 and PTEN expression with well-established clinicopathological prognostic factors and evaluate their prognostic significance by examining their potential interactions in endometrial carcinoma, as such evidence in the literature is poor.

\section{Materials and methods}

Patients. A total of 99 women with primary endometrial carcinoma and who underwent surgery were randomly selected and analyzed retrospectively. The mean age of the patients was 64 years old (range, 42-90 years old). The standard primary treatment for patients with endometrial carcinoma and localized disease was surgery, which consisted of total abdominal hysterectomy and salpingo-oophorectomy. Adjuvant radiation therapy was postoperatively administered in patients with $\geq 50 \%$ invasion of the myometrium, a histologic grade of 3 or a nonendometrioid histologic type. None of the patients examined had received irradiation, hormonal therapy or chemotherapy prior to surgery. Clinical staging for all patients was performed with computerized tomography scanning and magnetic resonance imaging. Patients with metastases in the pelvic or paraaortic lymph nodes were excluded from the study (FIGO stages IIIc and IVb). In all patients with endometrial carcinoma, the following histopathologic parameters were determined: Histologic type and grade, depth of myometrial invasion, lymphovascular space invasion, fallopian tube and/or ovarian invasion and presence of tumor necrosis. Histologic grades (tumor differentiation) of endometrial carcinomas were based on the ratio of glandular or papillary structures vs. solid tumor growth (grade 1, <5\% solid tumor; grade 2, 6-50\% solid; and grade $3,>50 \%$ solid). The depth of myometrial invasion was defined as the percentage of the myometrium invaded by the carcinoma. Lymphovascular invasion was considered to be present when cancerous cells were within or attached to the wall of a capillary-like space.

Histopathologic analysis. For histological examination, endometrial carcinoma specimens were routinely fixed with formalin, embedded in paraffin, sliced into thin sections and stained with hematoxylin and eosin. Four-micrometers-thick sections included sufficient quantities of neoplasm mass. The sections were mounted on silane-coated glass slides.

Immunohistochemical analysis for p53 and PTEN. The following primary antibodies were used for analysis: Mouse monoclonal anti-p53 antibody (clone DO-7; Thermo Fisher Scientific Inc., Waltham, MA, USA) and monoclonal PTEN (clone MMAC; Novocastra, Newcastle, UK). Immunohistochemical staining was performed on tissue sections deparaffinized in xylene, using the standard avidin-biotin-peroxidase complex method with an automated immunostainer (Benchmark XT; Ventana Medical System,
Inc., Tuscon, AZ, USA). Sections were incubated for $45 \mathrm{~min}$ at room temperature with a diluted solution of primary antibodies (1:200 for p53 and 1:100 for PTEN). Visualization was performed using a DAKO EnVision immunostainer. The final stage involved dehydration and coverage of the tile.

Evaluation of immunohistochemistry. A total of 100 cells were counted in 10 random fields (with x400 objectives) and the percentage of positive cells was calculated. The semi-quantitative immunoreaction scoring system was evaluated based on the percentage of positive cells added to the stain intensity.

Regarding stain intensity, negative staining was defined as 0 , weakly positive was defined as 1 , moderately positive as 2 and strongly positive as 3 . The scores of immunopositive positive cells were defined as follows: $<5 \%$ positive cells was defined as 0 (negative); 5-25\% immunopositive positive cells as 1 (low); $25-75 \%$ immunopositive cells as 2 (moderate); and $>75 \%$ immunopositive positive cells as 3 (high). The sum of the stain intensity and positive cell scores was the result for each section. It was determined as $-(0),+(1,2),++(3,4)$, and $+++(5,6)$. Fig. $1 \mathrm{~A}$ and $\mathrm{B}$ indicate the positive immunohistochemical expression of p53 in the nucleus. Fig. 1C-E indicate the positive immunohistochemical expression of PTEN in the nucleus.

Statistical analysis. Categorical variables were presented as absolute (n) and relative (\%) frequencies, while continuous variables were presented as median (min, max). Associations between categorical variables were assessed using exact Pearson's $\chi^{2}$ test. For continuous variables, differences in the median between two groups were assessed using the Mann-Whitney $U$ test and differences between three groups were assessed with the Kruskal-Wallis test. Correlations between continuous variables were assessed with Spearman's rho $(\rho)$. Statistical significance was set at a two-tailed P-value of $<0.05$. Data were analyzed using SPSS software, version 23.0 (IBM Corporation, Armonk, NY, USA).

\section{Results}

Assessment of histologic types indicated that $86(86.9 \%)$ cases of endometrial carcinoma were endometrioid and 13 (13.1\%) cases were non-endometrioid. Assessment of histologic grades revealed that $20(20.2 \%)$ cases were in grade $1,49(49.5 \%)$ cases were in grade 2 and $30(30.3 \%)$ cases were in grade 3. According to tumor depth assessment, 34 (34.3\%) cases had $<50 \%$ myometrial invasion and $65(65.7 \%)$ cases had $>50 \%$. Disease clinical stage classification revealed that $68(68.7 \%)$ cases were in stage I, $15(15.2 \%)$ cases were in stage II and $5(5.1 \%)$ cases were in stage III. Lymph-vascular space invasion was identified in $14(14.1 \%)$ cases, while fallopian tube and ovarian invasion was revealed in 19 (19.1\%) cases. Tumor necrosis was detected in 7 (7.1\%) cases.

Table I indicates the characteristics of the 99 patients with endometrial carcinoma, whereas Table II indicates the clinicopathological parameters of the patients according to the histologic subtypes.

p53 immunohistochemistry. Scores of p53 immunohistochemical expression were not significantly associated with the 
Table I. Clinicopathological characteristics of endometrial adenocarcinomas according to histological subtypes.

\begin{tabular}{|c|c|c|}
\hline Clinicopathological parameters & $\begin{array}{c}\text { Endometrioid } \\
\text { adenocarcinomas }(\mathrm{n}=86) \\
\text { cases, } \mathrm{n}(\%)\end{array}$ & $\begin{array}{c}\text { Clear cell and papillary } \\
\text { serous adenocarcinomas }(\mathrm{n}=13) \\
\text { cases, } \mathrm{n}(\%)\end{array}$ \\
\hline \multicolumn{3}{|l|}{ Age (years) } \\
\hline$<60$ & $23(26.7)$ & $0(0.0)$ \\
\hline$>60$ & $63(73.3)$ & $13(100.0)$ \\
\hline \multicolumn{3}{|l|}{ Clinical stage } \\
\hline I & $62(72.1)$ & $6(46.2)$ \\
\hline II & $10(11.6)$ & $5(38.5)$ \\
\hline III & $4(4.7)$ & $1(7.7)$ \\
\hline IV & $0(0.0)$ & $0(0.0)$ \\
\hline \multicolumn{3}{|l|}{ Histological differentiation } \\
\hline G1 & $20(23.3)$ & $0(0.0)$ \\
\hline G2 & $47(54.7)$ & $2(15.4)$ \\
\hline G3 & $19(22.1)$ & $11(84.6)$ \\
\hline \multicolumn{3}{|l|}{ Myometrial invasion } \\
\hline$<1 / 2$ & $32(37.2)$ & $2(15.4)$ \\
\hline$\geq 1 / 2$ & $54(62.8)$ & $11(84.6)$ \\
\hline \multicolumn{3}{|l|}{ Lymph-vascular space invasion } \\
\hline Positive & $10(11.6)$ & $4(30.8)$ \\
\hline Negative & $44(51.2)$ & $7(53.8)$ \\
\hline \multicolumn{3}{|c|}{ Fallopian tube and/or ovarian invasion } \\
\hline Positive & $12(14.0)$ & $7(53.8)$ \\
\hline Negative & $25(29.1)$ & $2(15.4)$ \\
\hline \multicolumn{3}{|l|}{ Tumoral necrosis } \\
\hline Yes & $5(5.8)$ & $2(15.4)$ \\
\hline No & $43(50.0)$ & $9(69.2)$ \\
\hline
\end{tabular}

mean age of the patients $(\mathrm{P}=0.131)$, histologic types $(\mathrm{P}=0.349)$, clinical stages $(\mathrm{P}=0.100)$, histologic grades $(\mathrm{P}=0.165)$, depth of myometrial invasion $(\mathrm{P}=0.323)$ or the presence of tumor necrosis $(\mathrm{P}=0.313)$. However, there was a significant association between lymph-vascular space invasion and scores of immunohistochemical p53 expression $(\mathrm{P}=0.007)$. In the presence of lymph-vascular space invasion, immunopositivity for p53 was detected in $25-75 \%$ of cells in 10 (90.9\%) cases and in $>75 \%$ of cells in $1(9.1 \%)$ case. In the absence of lymph-vascular space invasion, 5-25\% immunopositive cells were identified in $17(33.3 \%)$ cases, $25-75 \%$ in $22(43.1 \%)$ cases and $>75 \%$ in $1(2.0 \%)$ case. Patients with lymph-vascular space invasion had a larger percentage of immunopositivity for p53 compared with patients without lymph-vascular space invasion.

The intensity of p53 expression was not significantly associated with the mean age of patients $(\mathrm{P}=0.489)$, histologic grades $(\mathrm{P}=0.539)$, histologic types $(\mathrm{P}=0.191)$, depth of myometrial invasion $(\mathrm{P}=0.696)$, clinical stage $(\mathrm{P}=0.253)$, lymph-vascular space invasion $(\mathrm{P}=0.185)$, the presence of tumor necrosis $(\mathrm{P}=0.411)$ or fallopian tube invasion $(\mathrm{P}=0.321)$.

Table III reveals the sum of stain intensity and scores of p53-immunopositive cells and the association of this with the clinicopathological characteristics. There was a significant association between the sum of stain intensity and scores of p53-immunopositive cells and the age of the patients $(\mathrm{P}=0.037)$, histologic subtypes $(\mathrm{P}=0.008)$, histologic grades $(\mathrm{P}=0.002)$ and fallopian tube and/or ovarian invasion $(\mathrm{P}=0.014)$. In addition, results implied the association between the sum of stain intensity and scores of p53-immunopositive cells with clinical stage $(\mathrm{P}=0.089)$.

PTEN immunohistochemistry. The scores of immunohistochemical expression of PTEN were not significantly associated with the mean age of the patients $(\mathrm{P}=0.844)$, histologic grade $(\mathrm{P}=0.352)$, lymph-vascular space invasion $(\mathrm{P}=0.451)$ or the presence of tumor necrosis $(\mathrm{P}=1.000)$. There was a negative statistical significance between the scores of PTEN immunohistochemical expression and the depth of myometrial invasion $(\mathrm{P}=0.002 ; \rho=-0.377)$. Among the 28 cases that demonstrated positive immunostaining for PTEN in $5-25 \%$ of cells, $6(21.4 \%)$ cases had a depth of myometrial invasion less than half the thickness of the myometrium, 1 (3.6\%) case had a depth of myometrial invasion equal to half the thickness of the myometrium, 7 (25.0\%) cases had a depth of myometrial invasion equal to two thirds of the thickness of the myometrium, $7(25.0 \%)$ cases had a depth of myometrial invasion equal to three quarters of the thickness of the myometrium and $7(25.0 \%)$ cases had a depth of myometrial invasion equal 

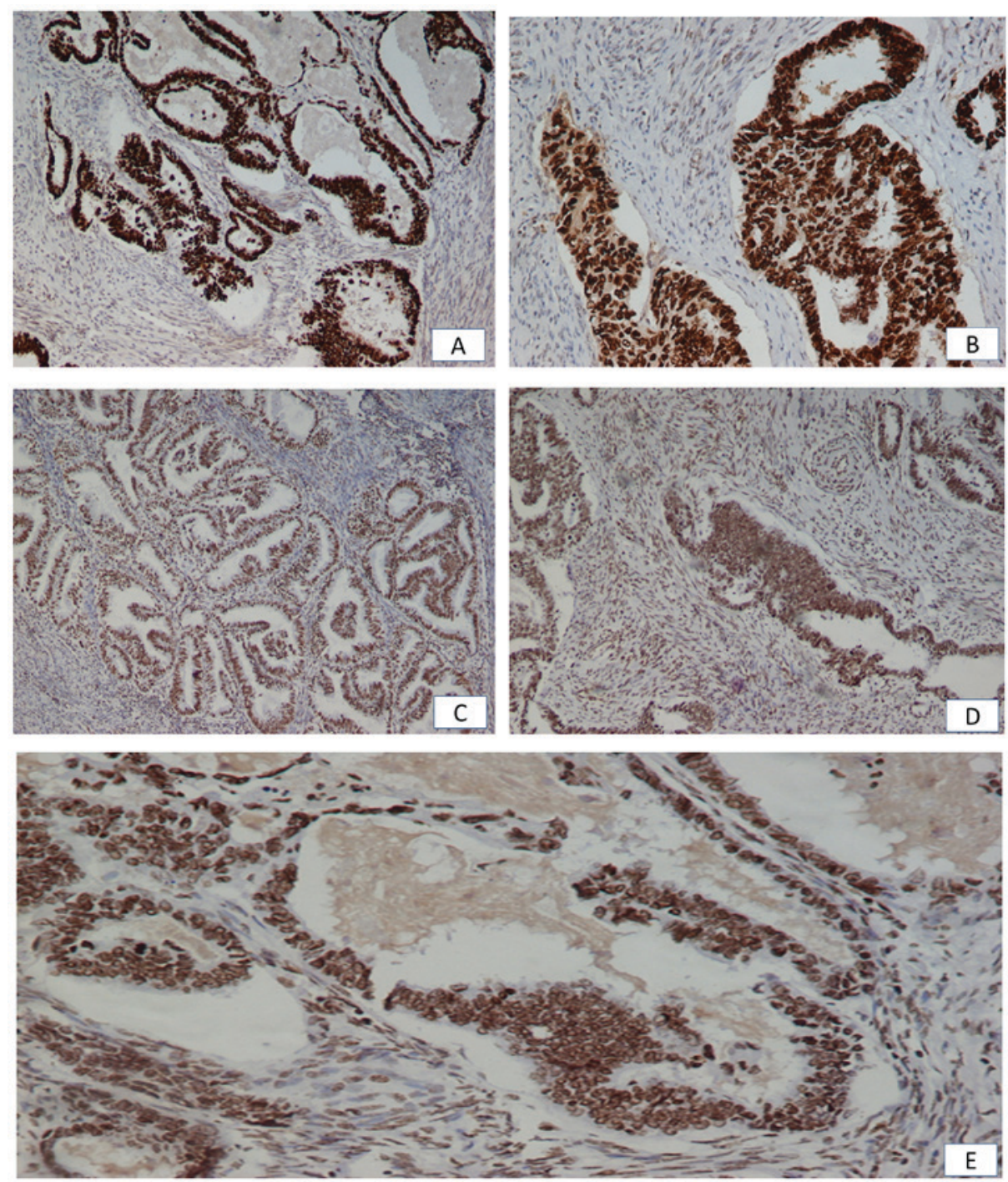

Figure 1. (A) Endometrial carcinoma: Positive immunohistochemical expression of p53 in the nucleus (magnification, x100). (B) Endometrial carcinoma: Positive immunohistochemical expression of p53 in the nucleus (magnification, x200). (C) Endometrial carcinoma: Positive immunohistochemical expression of PTEN in the nucleus (magnification, x100). (D) Endometrial carcinoma: Positive immunohistochemical expression of PTEN in the nucleus (magnification, x200), (E) Endometrial carcinoma: Positive immunohistochemical expression of PTEN in the nucleus (magnification, x400). PTEN, phosphatase and tensin homolog.

to the entire thickness of the myometrium. Regarding the 27 cases that exhibited positive immunostaining for PTEN in $25-75 \%$ of cells, $6(22.2 \%)$ cases had a depth of myometrial invasion less than half the thickness of the myometrium, $10(37.0 \%)$ cases had a depth of myometrial invasion equal to half the thickness of the myometrium, 1 (3.7\%) case had a depth of myometrial invasion equal to two thirds of the thickness of the myometrium, 4 (14.8\%) cases had a depth of myometrial invasion equal to three quarters of the thickness of the myometrium, $2(7.4 \%)$ cases had a depth equal to the superficial lining of the myometrium and 4 (14.8\%) cases had a depth of myometrial invasion equal to the entire thickness of the myometrium. Among the 13 cases that demonstrated positive immunostaining for PTEN in $>75 \%$ of cells, $4(30.8 \%)$ cases had a depth of myometrial invasion less than half the thickness of the myometrium, $3(23.1 \%)$ cases had a depth of myometrial invasion equal to half the thickness of the myometrium, $1(7.7 \%)$ case had a depth of myometrial invasion equal to three quarters of the thickness of the myometrium, $4(30.8 \%)$ cases had a depth equal to the superficial lining of the myometrium and $1(7.7 \%)$ case had a depth of myometrial invasion equal to the entire thickness of the myometrium.

Notably, there was a significant correlation between the scores of immunohistochemical PTEN expression and the clinical stage $(\mathrm{P}=0.019)$. Among those classified as clinical stage $\mathrm{I}$, $18(26.5 \%)$ cases exhibited 5-25\% PTEN-immunopositive cells, $22(32.4 \%)$ cases exhibited $25-75 \%$ PTEN-immunopositive cells and $13(19.1 \%)$ cases exhibited $>75 \%$ PTEN-immunopositive cells. In clinical stage II, immunopositivity for PTEN was detected in $5-25 \%$ of cells in $6(40.0 \%)$ cases, whereas there were no cases with immunopositivity for PTEN in $25-75 \%$ or in $>75 \%$ of cells. Finally, in clinical stage III, 2 (40.0\%) cases had 5-25\% PTEN-immunopositive cells and another $2(40.0 \%)$ cases exhibited $25-75 \%$ PTEN-immunopositive cells.

The intensity of PTEN expression was not significantly associated with the mean age of patients $(\mathrm{P}=0.387)$, histologic type of the tumor $(\mathrm{P}=0.630)$, depth of myometrial invasion $(\mathrm{P}=0.124)$, clinical stage $(\mathrm{P}=0.621)$, lymph-vascular space invasion $(\mathrm{P}=0.442)$, presence of tumor necrosis $(\mathrm{P}=1.000)$ or the presence of fallopian tube invasion $(\mathrm{P}=0.524)$. Furthermore, 

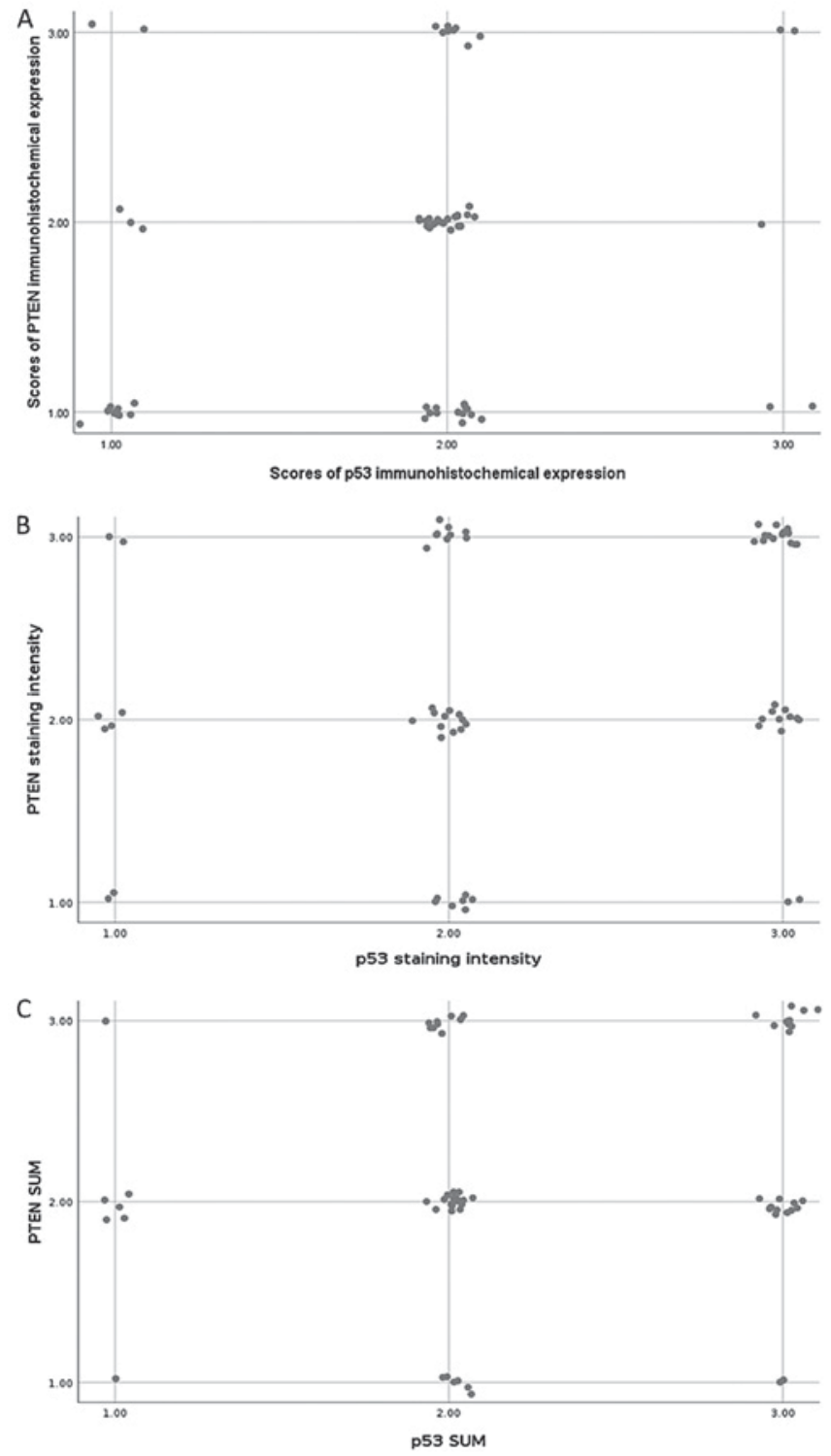

Figure 2. Scatterplot of the association between positive immunostaining scores for p53 and PTEN. (A) The scatterplot was created with jittering of the position of the data points to avoid overplotting. (B) Scatterplot of the association between staining intensity for p53 and PTEN. The scatterplot was created with jittering of the position of the data points to avoid overplotting. (C) Scatterplot of the association between the sum of stain intensity and scores of p53- and PTEN-positive cells. The scatterplots were created with jittering of the position of the data points to avoid overplotting. PTEN, phosphatase and tensin homolog.

the results suggested that there was no significant association was observed between the intensity of PTEN staining and histologic grade $(\mathrm{P}=0.071)$. Strong positive PTEN expression was observed in $4(20.0 \%)$ cases of histologic grade G1, in $21(42.9 \%)$ cases of grade G2 and in $5(16.7 \%)$ cases of histologic grade $\mathrm{G} 3$. The corresponding frequencies for moderate PTEN expression were 9 (45.0\%), 17 (34.7\%) and 14 (46.7\%), respectively.

Table IV indicates the sum of stain intensity and scores of PTEN-immunopositive cells and the association of this with the clinicopathological characteristics. There was no correlation between the sum of stain intensity and scores of PTEN-immunopositive cells and the age of the patients $(\mathrm{P}=0.371)$, histologic subtype $(\mathrm{P}=1.000)$, histologic grade
Table II. Characteristics of the 99 endometrial adenocarcinoma patients.

Clinicopathological parameters

No. of patients $(\%)$

Age (years)

$<60$

$23(23.2)$

$\geq 60$

$76(76.8)$

Clinical stage

I

68 (68.7)

II

$15(15.2)$

III

Histological differentiation

G1

$20(20.2)$

$\mathrm{G} 2$

49 (49.5)

G3

$30(30.3)$

Myometrial invasion

$<1 / 2$

$34(34.3)$

$\geq 1 / 2$

Lymph-vascular space invasion

Positive

Negative

Fallopian tube and ovarian invasion

Positive

19 (19.2)

Negative

Tumoral necrosis

Yes

No

$(\mathrm{P}=0.439)$, myometrial invasion $(\mathrm{P}=0.308)$, clinical stage $(\mathrm{P}=0.259)$, ovarian or fallopian tube invasion $(\mathrm{P}=0.752)$ or the presence of tumor necrosis $(\mathrm{P}=1.000)$.

Concomitant expression of 553 and PTEN and the association with clinicopathogical parameters. According to the scores of immunopositive endometrial carcinoma cells, p53 expression was identified in $73(85 \%)$ cases and PTEN expression was indicated in $64(74 \%)$ cases. According to the intensity of immunopositive cells, p53 and PTEN expression was indicated in $74(86 \%)$ and $66(77 \%)$ cases, respectively. According to the sum of stain intensity and scores of positive cells, endometrial carcinoma samples had a lower proportion of PTEN-positive results $(77.1 \%)$ compared with p53-postive results $(89.2 \%)$. Notably, $17 \%$ of patients exhibited PTEN(-)/p53(+) expression, whereas $4.8 \%$ of patients exhibited PTEN(+)/p53(-). In addition, p53 and PTEN concomitant sum expression was identified in $45 \%$ of patients with endometrial adenocarcinoma.

According to the proportion (score) of immunopositive cells, there was a coexistence of p53 and PTEN expression in $53.2 \%$ (33/62) of cases (group A) compared with 46.8\% (29/62) of cases, in which there was an absence of p53 and PTEN co-expression (group B). Spearman's coefficient for co-expression of p53 and PTEN was $\rho=0.248(\mathrm{P}=0.052)$, which was marginal for statistical significance. This correlation was indicated in the scatterplot (Fig. 2A). Low concomitant staining was identified in $16.1 \%$ of patients, moderate concomitant 
Table III. Correlations between clinicopathological characteristics and sum of stain intensity and scores of p53 expression.

\begin{tabular}{|c|c|c|c|c|c|c|}
\hline \multirow[b]{2}{*}{ Characteristics } & \multirow[b]{2}{*}{ Cases, n (\%) } & \multicolumn{4}{|c|}{$\mathrm{IHC}$ results of $\mathrm{p} 53, \mathrm{~N}(\%)$} & \multirow[b]{2}{*}{ P-value } \\
\hline & & 0 & + & ++ & +++ & \\
\hline \multicolumn{7}{|l|}{ Age (years) } \\
\hline$<60$ & $23(23.2)$ & $0(0.0)$ & $4(33.3)$ & $16(38.1)$ & $3(10.3)$ & 0.037 \\
\hline$\geq 60$ & $76(76.8)$ & $0(0.0)$ & $8(66.7)$ & $26(61.9)$ & $26(89.7)$ & \\
\hline \multicolumn{7}{|l|}{ Histological type } \\
\hline Endometrioid & $86(86.9)$ & $0(0.0)$ & $12(100.0)$ & $40(95.2)$ & $21(72.4)$ & 0.008 \\
\hline Clear cell and papillary serous & $13(13.1)$ & $0(0.0)$ & $0(0.0)$ & $2(4.8)$ & $8(27.6)$ & \\
\hline \multicolumn{7}{|l|}{ Clinical stage } \\
\hline I & $68(68.7)$ & $0(0.0)$ & $8(66.7)$ & $34(81.0)$ & $17(58.6)$ & 0.089 \\
\hline II & $15(15.2)$ & $0(0.0)$ & $1(8.3)$ & $2(4.8)$ & $6(20.7)$ & \\
\hline III & $5(5.1)$ & $0(0.0)$ & $0(0.0)$ & $1(2.4)$ & $3(10.3)$ & \\
\hline \multicolumn{7}{|l|}{ Histological differentiation } \\
\hline G1 & $20(20.2)$ & $0(0.0)$ & $3(25.0)$ & $7(16.7)$ & $7(24.1)$ & 0.002 \\
\hline G2 & $49(49.5)$ & $0(0.0)$ & $8(66.7)$ & $26(61.9)$ & $6(20.7)$ & \\
\hline G3 & $30(30.3)$ & $0(0.0)$ & $1(8.3)$ & $9(21.4)$ & $16(55.2)$ & \\
\hline \multicolumn{7}{|l|}{ Myometrial invasion } \\
\hline$<1 / 2$ & $34(34.3)$ & $0(0.0)$ & $5(41.7)$ & $16(38.1)$ & $9(31.0)$ & 0.778 \\
\hline$\geq 1 / 2$ & $65(65.7)$ & $0(0.0)$ & $7(58.3)$ & $26(61.9)$ & $20(69.0)$ & \\
\hline \multicolumn{7}{|l|}{ Lymph-vascular space invasion } \\
\hline Positive & $14(14.1)$ & $0(0.0)$ & $0(0.0)$ & $6(14.3)$ & $5(17.2)$ & 0.101 \\
\hline Negative & $51(51.5)$ & $0(0.0)$ & $10(83.3)$ & $22(52.4)$ & $9(31.0)$ & \\
\hline \multicolumn{7}{|c|}{ Fallopian tube and/or ovarian invasion } \\
\hline Positive & $19(19.2)$ & $0(0.0)$ & $1(8.3)$ & $4(9.5)$ & $8(27.6)$ & 0.014 \\
\hline Negative & $27(27.3)$ & $0(0.0)$ & $7(58.3)$ & $15(357)$ & $4(13.8)$ & \\
\hline \multicolumn{7}{|l|}{ Tumoral necrosis } \\
\hline Yes & $7(7.1)$ & $0(0.0)$ & $1(8.3)$ & $2(4.8)$ & $3(10.3)$ & 0.524 \\
\hline No & $52(52.5)$ & $0(0.0)$ & $9(75.0)$ & $22(52.4)$ & $10(34.5)$ & \\
\hline
\end{tabular}

$\mathrm{P}<0.05$ : Statistically significant results.

staining was identified in $33.9 \%$ of patients and high concomitant staining was identified in $3.2 \%$ of patients. Additionally, $40.0 \%$ of patients with high scores of p53 expression also had high scores of PTEN expression (2/5 patients), whereas $15.4 \%$ of patients with high PTEN scores exhibited high scores of p53 (2/13 patients).

According to the staining intensity, weak concomitant staining was indicated in $3.2 \%$ of patients, moderate concomitant staining was indicated in $19.0 \%$ of patients and strong concomitant staining was indicated in $23.8 \%$. A total of $44.1 \%$ of patients with strong levels of p53 expression also exhibited strong PTEN expression (15/34 patients), whereas $50.0 \%$ of patients with strong PTEN levels exhibited strong levels of p53 expression (15/30 patients). There was a significantly positive correlation between the intensity of PTEN and p53 staining. Spearman's coefficient for the staining intensity of p53 and PTEN co-expression was $\rho=0.282$ ( $\mathrm{P}=0.025$; Fig. $2 \mathrm{~B}$ ). This suggests that strong PTEN staining was associated with strong p53 staining and vice versa.

According to the sum of stain intensity and scores of positive cells, + concomitant staining was indicated in $1.6 \%$ of patients, ++ was indicated in $27.4 \%$ and +++ was indicated in $16.1 \%$ of patients. Notably, $34.5 \%$ of patients with +++ p53 staining also had +++ PTEN staining (10/29 patients), whereas $45.5 \%$ of patients with +++ PTEN staining levels exhibited +++ p53 staining (10/22 patients). Furthermore, it was demonstrated that the sum of stain intensity and scores of p53-immunopositive cells significantly correlated with PTEN expression ( $\rho=0.256 ; \mathrm{P}=0.044$; Fig. $2 \mathrm{C}$ ).

According to the proportion (scores) of immunopositive cells, the age of patients was significantly different between the two groups; 33 cases with the coexistence of p53 and PTEN (group A) and the remaining 29 cases without the coexistence of p53 and PTEN (group B; $\mathrm{P}=0.002$ ).

The scores of immunopositive cells between group A and group B were not significantly associated with the histologic type of the tumor $(\mathrm{P}=0.595)$, histologic grade $(\mathrm{P}=0.259)$, depth of myometrial invasion $(\mathrm{P}=0.224)$, lymph-vascular space invasion $(\mathrm{P}=0.253)$, presence of tumor necrosis $(\mathrm{P}=0.340)$ or fallopian tube invasion $(\mathrm{P}=1.000)$.

To further study the co-expression of p53 and PTEN, patients were divided into three groups that were defined as 
Table IV. Correlations between clinicopathological characteristics and sum of stain intensity and scores of PTEN expression.

\begin{tabular}{|c|c|c|c|c|c|c|}
\hline \multirow[b]{2}{*}{ Characteristics } & \multirow[b]{2}{*}{ Cases $(\mathrm{N})$} & \multicolumn{4}{|c|}{ Immunohistochemistry results of PTEN (N) } & \multirow[b]{2}{*}{ P-value } \\
\hline & & 0 & + & ++ & +++ & \\
\hline \multicolumn{7}{|l|}{ Age (years) } \\
\hline$<60$ & 19 & $0(0.0)$ & $1(10.0)$ & $12(33.3)$ & $6(27.3)$ & \multirow[t]{2}{*}{0.371} \\
\hline$\geq 60$ & 49 & $0(0.0)$ & $9(90.0)$ & $24(66.7)$ & $16(72.7)$ & \\
\hline \multicolumn{7}{|l|}{ Histological type } \\
\hline Endometrioid & 64 & $0(0.0)$ & $9(90.0)$ & $34(94.4)$ & $22(5.5)$ & \multirow[t]{2}{*}{1.000} \\
\hline Clear cell and papillary serous & 4 & $0(0.0)$ & $1(10.0)$ & $2(5.6)$ & $1(4.5)$ & \\
\hline \multicolumn{7}{|l|}{ Clinical stage } \\
\hline I & 53 & $0(0.0)$ & $8(80.0)$ & $24(66.7)$ & $21(95.5)$ & \multirow[t]{3}{*}{0.259} \\
\hline II & 6 & $0(0.0)$ & $1(10.0)$ & $5(13.9)$ & $0(0.0)$ & \\
\hline III & 4 & $0(0.0)$ & $0(0.0)$ & $3(8.3)$ & $1(4.5)$ & \\
\hline \multicolumn{7}{|l|}{ Histological differentiation } \\
\hline G1 & 13 & $0(0.0)$ & $1(10.0)$ & $8(22.2)$ & $4(18.2)$ & \multirow[t]{3}{*}{0.439} \\
\hline G2 & 36 & $0(0.0)$ & $4(40.0)$ & $18(50.0)$ & $14(63.6)$ & \\
\hline G3 & 19 & $0(0.0)$ & $5(50.0)$ & $10(27.8)$ & $4(18.2)$ & \\
\hline \multicolumn{7}{|l|}{ Myometrial invasion } \\
\hline$<1 / 2$ & 22 & $0(0.0)$ & $3(30.0)$ & $9(25.0)$ & $10(45.5)$ & \multirow[t]{2}{*}{0.308} \\
\hline$\geq 1 / 2$ & 46 & $0(0.0)$ & $7(70.0)$ & $27(75.0)$ & $12(54.5)$ & \\
\hline \multicolumn{7}{|l|}{ Lymph-vascular space invasion } \\
\hline Positive & 11 & $0(0.0)$ & $3(30.0)$ & $6(16.7)$ & $2(9.1)$ & \multirow[t]{2}{*}{0.292} \\
\hline Negative & 24 & $0(0.0)$ & $4(40.0)$ & $19(52.8)$ & $1(4.5)$ & \\
\hline \multicolumn{7}{|c|}{ Fallopian tube and ovarian invasion } \\
\hline Positive & 8 & $0(0.0)$ & $1(10.0)$ & $7(19.4)$ & $0(0.0)$ & \multirow[t]{2}{*}{0.752} \\
\hline Negative & 18 & $0(0.0)$ & $4(40.0)$ & $13(36.1)$ & $1(4.5)$ & \\
\hline \multicolumn{7}{|l|}{ Tumoral necrosis } \\
\hline Yes & 5 & $0(0.0)$ & $1(10.0)$ & 4 (11.1) & $0(0.0)$ & \multirow[t]{2}{*}{1.000} \\
\hline No & 24 & $0(0.0)$ & $4(40.0)$ & $19(52.8)$ & $1(4.5)$ & \\
\hline
\end{tabular}

follows: Patients with low p53 and PTEN expression scores; patients with moderate expression scores of either p53 or PTEN; and patients with high expression scores of p53 and PTEN. Table V summarizes the distribution of the co-expression of p53 and PTEN in endometrial carcinomas according to scores of immunopositive cells in correlation with clinicopathological characteristics. Notably, there was a correlation between the scores of p53 and PTEN co-expression and the age of the patients $(\mathrm{P}=0.008)$ and histologic grade $(\mathrm{P}=0.028)$. The findings also suggested a correlation between the scores of p53 and PTEN co-expression and lymphovascular invasion $(\mathrm{P}=0.084)$. Table VI indicates the distribution of $\mathrm{p} 53$ and PTEN co-expression in endometrial carcinomas according to the stain intensity in correlation with clinicopathological characteristics. Furthermore, Table VII demonstrates p53 and PTEN co-expression in endometrial carcinomas according to the sum of stain intensity and immunoexpression scores.

\section{Discussion}

The overall rate of p53 and PTEN positivity in the present study was 89 and $77 \%$, respectively, according to sum of stain intensity and scores of immunopositive cells. In the study, the intensity of p53 and PTEN staining was positively correlated ( $\rho=0.282 ; P=0.025$ ). Furthermore, the sum of stain intensity and immunohistochemical scores of p53 was positively correlated with PTEN expression $(\rho=0.256 ; \mathrm{P}=0.044)$. The findings indicate an intrinsic association between the overexpression of the two major tumors suppressor genes, p53 and PTEN. This supports the previous suggestions that $\mathrm{p} 53$ induces PTEN expression and PTEN reduces p53-induced degradation (20). Notably, p53 and PTEN concomitant expression was demonstrated in $45 \%$ of patients with endometrial adenocarcinoma, and was considered a common event.

Previous findings have indicated that p53 alterations seem to occur at early and late phases of endometrial carcinogenesis $(43,44)$. Early involvement of p53 alterations in endometrial carcinogenesis has been suggested because p53 has been indicated to be expressed in endometrial glands adjacent to endometrial carcinoma and it is associated with endometrial hyperplasia (30). In the present study, no correlation was indicated with the sum of stain intensity and scores of p53-immunopositive cells and clinical stage $(\mathrm{P}=0.089)$, depth of myometrial invasion $(\mathrm{P}=0.778)$ or lymph-vascular space invasion $(\mathrm{P}=0.101)$. Therefore, the findings support the hypothesis that p53 alterations occur at early and late phases of 
Table V. Co-expression of p53 and PTEN in endometrial carcinomas according to scores of immunopositive cells in relation to clinopathological parameters.

\begin{tabular}{|c|c|c|c|c|}
\hline Characteristics & $\begin{array}{l}\text { Patients with p53 } \\
\text { and PTEN low } \\
\text { scores expression } \\
\text { cases, n }(\%)\end{array}$ & $\begin{array}{l}\text { Patients with either } \\
\text { p53 or PTEN moderate } \\
\text { scores expression } \\
\text { cases, } n(\%)\end{array}$ & $\begin{array}{l}\text { Patients with p53 } \\
\text { and PTEN high } \\
\text { scores expression } \\
\text { cases, n }(\%)\end{array}$ & P-value \\
\hline \multicolumn{5}{|l|}{ Age (years) } \\
\hline$<60$ & $7(70.0)$ & $15(24.6)$ & $0(0.0)$ & \multirow[t]{2}{*}{0.008} \\
\hline$\geq 60$ & $3(30.0)$ & $46(75.4)$ & $2(100.0)$ & \\
\hline \multicolumn{5}{|l|}{ Histological type } \\
\hline Endometrioid & $10(100.0)$ & $53(86.9)$ & $1(50.0)$ & \multirow[t]{2}{*}{0.106} \\
\hline Clear cell and papillary serous & $0(0.0)$ & $8(13.1)$ & $1(50.0)$ & \\
\hline \multicolumn{5}{|l|}{ Clinical stage } \\
\hline $\mathrm{I}$ & $9(90.0)$ & $44(72.1)$ & $2(100.0)$ & \multirow[t]{3}{*}{0.876} \\
\hline II & $1(10.0)$ & $4(6.6)$ & $0(0.0)$ & \\
\hline III & $0(0.0)$ & $5(8.2)$ & $0(0.0)$ & \\
\hline \multicolumn{5}{|l|}{ Histological differentiation } \\
\hline G1 & $2(20.0)$ & $14(23.0)$ & $0(0.0)$ & \multirow[t]{3}{*}{0.028} \\
\hline $\mathrm{G} 2$ & $8(80.0)$ & $27(44.3)$ & $0(0.0)$ & \\
\hline G3 & $0(0.0)$ & $20(32.8)$ & $2(100.0)$ & \\
\hline \multicolumn{5}{|l|}{ Myometrial invasion } \\
\hline$<1 / 2$ & $3(30.0)$ & $22(36.1)$ & $0(0.0)$ & \multirow[t]{2}{*}{0.651} \\
\hline$\geq 1 / 2$ & $7(70.0)$ & $39(63.9)$ & $2(100.0)$ & \\
\hline \multicolumn{5}{|l|}{ Lymph-vascular space invasion } \\
\hline Yes & $0(0.0)$ & $11(18.0)$ & $0(0.0)$ & \multirow[t]{2}{*}{0.084} \\
\hline No & $9(90.0)$ & $23(37.7)$ & $0(0.0)$ & \\
\hline \multicolumn{5}{|c|}{ Fallopian tube and/or ovarian invasion } \\
\hline Yes & $1(10.0)$ & $8(13.1)$ & $0(0.0)$ & \multirow[t]{2}{*}{0.642} \\
\hline No & $5(50.0)$ & $17(27.9)$ & $0(0.0)$ & \\
\hline \multicolumn{5}{|l|}{ Tumoral necrosis } \\
\hline Yes & $1(10.0)$ & $4(6.6)$ & $0(0.0)$ & \multirow[t]{2}{*}{1.000} \\
\hline No & $8(80.0)$ & $24(39.3)$ & $0(0.0)$ & \\
\hline
\end{tabular}

$\mathrm{P}<0.05$ : Statistically significant results.

the endometrial carcinoma progression. In the literature, it has been demonstrated that overexpression of p53 in endometrioid adenocarcinomas of the uterus were significantly higher in serous papillary (in 75-90\% of cases) compared with endometrioid endometrial carcinomas (in 10-35\% of cases) (45-70). In patients with endometrial carcinoma, overexpression of p53 has been indicated to be a significantly negative prognostic factor and associated with poor differentiation, advanced stage, increased myometrial invasion, positive lymph node involvement and distant metastases (71-81). In the present study, there was a significant association between the scores of immunohistochemical p53 expression and lymph-vascular invasion $(\mathrm{P}=0.007)$, suggesting that a larger percentage of p53-immunopositive cells in endometrial carcinoma may be involved in the metastatic process of the disease. In addition, the sum of stain intensity and scores of p53 expression were significantly correlated with patient age $(\mathrm{P}=0.037)$, histologic type $(\mathrm{P}=0.008)$, histologic grade $(\mathrm{P}=0.002)$ and fallopian and/or ovarian invasion $(\mathrm{P}=0.014)$. The present findings indicate that p53 protein expression serves an important role in the differentiation and extension process of endometrial neoplastic cells in older patients. Daniilidou et al (70) revealed p53 expression, as a separate factor, was correlated with stage but not with histologic grade of endometriod endometrial adenocarcinoma; positive p53 expression correlated with stage IIIC, while the absence of p53 expression was connected with stages IB and IC. A key difference between the present study and the study by Daniilidou et al (70) was that all endometrial carcinomas (including endometrioid, clear cell and serous papillary adenocarcinomas) were examined as a whole in relation to the clinicopathological factors in the present study, whereas Daniilidou et al (70) separately studied the clinicopathological and immunohistochemical properties for endometrioid and serous papillary adenocarcinomas. The different results probably reflect the different pathways of carcinogenesis of type I and II endometrial carcinoma. In the literature, a reduced 5-year 
Table VI. Co-expression of p53 and PTEN in endometrial carcinomas according to stain intensity of immunopositive cells in relation to clinopathological parameters.

\begin{tabular}{|c|c|c|c|c|}
\hline Characteristics & $\begin{array}{l}\text { Patients with p53 } \\
\text { and PTEN weak } \\
\text { positive expression } \\
\text { cases, n }(\%)\end{array}$ & $\begin{array}{l}\text { Patients with either } \\
\text { p53 or PTEN moderate } \\
\text { positive expression } \\
\text { cases, } n(\%)\end{array}$ & $\begin{array}{l}\text { Patients with p53 } \\
\text { and PTEN strong } \\
\text { positive expression } \\
\text { cases, } \mathrm{n}(\%)\end{array}$ & P-value \\
\hline \multicolumn{5}{|l|}{ Age (years) } \\
\hline$<60$ & $1(50.0)$ & $16(31.4)$ & $2(13.3)$ & \multirow{2}{*}{0.261} \\
\hline$\geq 60$ & $1(50.0)$ & $35(68.6)$ & $13(86.7)$ & \\
\hline \multicolumn{5}{|l|}{ Histological type } \\
\hline Endometrioid & $2(100)$ & $48(94.1)$ & $14(93.3)$ & \multirow[t]{2}{*}{1.000} \\
\hline Clear cell and papillary serous & $0(0.0)$ & $3(5.9)$ & $1(6.7)$ & \\
\hline \multicolumn{5}{|l|}{ Clinical stage } \\
\hline I & $2(100.0)$ & $39(76.5)$ & $14(93.3)$ & \multirow[t]{3}{*}{0.685} \\
\hline II & $0(0.0)$ & $5(9.8)$ & $1(6.7)$ & \\
\hline III & $0(0.0)$ & $3(5.9)$ & $0(0.0)$ & \\
\hline \multicolumn{5}{|l|}{ Histological differentiation } \\
\hline G1 & $1(50.0)$ & $9(17.6)$ & $4(26.7)$ & \multirow[t]{3}{*}{0.801} \\
\hline $\mathrm{G} 2$ & $1(50.0)$ & $28(54.9)$ & $7(46.6)$ & \\
\hline G3 & $0(0.0)$ & $14(27.5)$ & $4(26.7)$ & \\
\hline \multicolumn{5}{|l|}{ Myometrial invasion } \\
\hline$<1 / 2$ & $1(50.0)$ & $16(31.4)$ & $7(46.7)$ & \multirow[t]{2}{*}{0.513} \\
\hline$\geq 1 / 2$ & $1(50.0)$ & $35(68.6)$ & $8(53.3)$ & \\
\hline \multicolumn{5}{|l|}{ Lymph-vascular space invasion } \\
\hline Yes & $0(0.0)$ & $8(15.7)$ & $1(6.7)$ & \multirow[t]{2}{*}{1.000} \\
\hline No & $1(50.0)$ & $27(52.9)$ & $2(13.3)$ & \\
\hline \multicolumn{5}{|c|}{ Fallopian tube and/or ovarian invasion } \\
\hline Yes & $0(0.0)$ & $7(13.7)$ & $1(6.7)$ & \multirow[t]{2}{*}{1.000} \\
\hline No & $1(50.0)$ & $18(35.3)$ & $1(6.7)$ & \\
\hline \multicolumn{5}{|l|}{ Tumoral necrosis } \\
\hline Yes & $0(0.0)$ & $4(7.8)$ & $1(6.7)$ & \multirow[t]{2}{*}{0.488} \\
\hline No & $1(50.0)$ & $26(51.0)$ & $2(13.3)$ & \\
\hline
\end{tabular}

$\mathrm{P}<0.05$ : Statistically significant results.

survival has been demonstrated $(71,75,80)$. However, there is controversy regarding the independent prognostic value of $\mathrm{p} 53$ expression using multivariate analysis. In particular, there are studies that have indicated p53 expression as an independent prognostic factor compared with FIGO stage, tumor grade and myometrial invasion $(71,75,79,82)$, whereas other studies have failed to demonstrate such independent prognostic value of p53 expression $(42,76,81,83)$. As a result, there are reservations about the routine use of this marker in clinical practice. For this reason, it is very important to examine how the expression of p53 potentially interacts with other tumor suppressor genes, and the prognostic significance of their concomitant expression in endometrial carcinoma.

In endometrial carcinoma, particularly in type I, mutations of PTEN have been described to occur in $25-83 \%$ of cases; however, mutations of PTEN have also been described to occur in endometrial hyperplasia $(\sim 55 \%)(13,15,84-88)$. In a study by Lacey et al (26), loss of PTEN expression in biopsies of endometrial hyperplasia was not associated with subsequent risk of endometrial carcinoma. Accordingly, inactivation of PTEN may be considered a crucial factor for early endometrial carcinogenesis. PTEN gene mutations have been revealed in more advanced stages of endometrial carcinoma (15). Loss of heterozygosity at chromosome 10q23 occurs in $\sim 40 \%$ of endometrial carcinomas $(89,90)$. It has been indicated that loss of PTEN expression was associated with endometrioid histology, and inversely associated with the presence of lymphovascular space invasion (91). Risinger et al (84) indicated that PTEN mutations were associated with low-grade and low-stage endometrial carcinomas, whereas Konopka et al (15) revealed a significant correlation between PTEN gene mutations and histologic grade of endometrial carcinomas, suggesting that defects in PTEN gene are associated with increased malignancy due to the loss of the ability of endometrial cells to differentiate. Other studies have indicated no correlation between PTEN expression and 
Table VII. Co-expression of p53 and PTEN in endometrial carcinomas according to sum of stain intensity and scores of immunopositive cells in relation to clinopathological parameters.

\begin{tabular}{|c|c|c|c|c|}
\hline Characteristics & $\begin{array}{l}\text { Patients with p53 and } \\
\text { PTEN + expression } \\
\text { cases, } \mathrm{n}(\%)\end{array}$ & $\begin{array}{l}\text { Patients with either p53 } \\
\text { or PTEN }++ \text { expression } \\
\text { cases, } \mathrm{n}(\%)\end{array}$ & $\begin{array}{c}\text { Patients with p53 and } \\
\text { PTEN + + + expression } \\
\text { cases, } \mathrm{n}(\%)\end{array}$ & P-value \\
\hline \multicolumn{5}{|l|}{ Age (years) } \\
\hline$<60$ & $1(100.0)$ & $20(32.8)$ & $1(10.0)$ & \multirow[t]{2}{*}{0.122} \\
\hline$\geq 60$ & $0(0.0)$ & $41(67.2)$ & $9(90.0)$ & \\
\hline \multicolumn{5}{|l|}{ Histological type } \\
\hline Endometrioid & $1(100.0)$ & $57(93.4)$ & $9(90.0)$ & \multirow[t]{2}{*}{1.000} \\
\hline Clear cell and papillary serous & $0(0.0)$ & $4(6.6)$ & $1(10.0)$ & \\
\hline \multicolumn{5}{|l|}{ Clinical stage } \\
\hline I & $1(100.0)$ & $46(75.4)$ & $10(100.0)$ & \multirow[t]{3}{*}{0.548} \\
\hline II & $0(0.0)$ & $6(9.8)$ & $0(0.0)$ & \\
\hline III & $0(0.0)$ & $3(4.9)$ & $0(0.0)$ & \\
\hline \multicolumn{5}{|l|}{ Histological differentiation } \\
\hline G1 & $0(0.0)$ & $11(18.0)$ & $4(40.0)$ & \multirow[t]{3}{*}{0.594} \\
\hline G2 & $1(100.0)$ & $34(55.7)$ & $4(40.0)$ & \\
\hline G3 & $0(0.0)$ & $16(26.2)$ & $2(20.0)$ & \\
\hline \multicolumn{5}{|l|}{ Myometrial invasion } \\
\hline$<1 / 2$ & $1(100.0)$ & $20(32.8)$ & $5(50.0)$ & \multirow[t]{2}{*}{0.271} \\
\hline$\geq 1 / 2$ & $0(0.0)$ & $41(67.2)$ & $5(50.0)$ & \\
\hline \multicolumn{5}{|l|}{ Lymph-vascular space invasion } \\
\hline Yes & $0(0.0)$ & $10(16.4)$ & $0(0.0)$ & \multirow[t]{2}{*}{0.762} \\
\hline No & $1(100.0)$ & $31(50.8)$ & $0(0.0)$ & \\
\hline \multicolumn{5}{|c|}{ Fallopian tube and/or ovarian invasion } \\
\hline Yes & $0(0.0)$ & $9(14.8)$ & $0(0.0)$ & \multirow[t]{2}{*}{1.000} \\
\hline No & $1(100.0)$ & $21(34.4)$ & $0(0.0)$ & \\
\hline \multicolumn{5}{|l|}{ Tumoral necrosis } \\
\hline Yes & $0(0.0)$ & $5(8.2)$ & $0(0.0)$ & \multirow[t]{2}{*}{1.000} \\
\hline No & $1(100.0)$ & $31(50.8)$ & $0(0.0)$ & \\
\hline
\end{tabular}

$\mathrm{P}<0.05$ : Statistically significant results.

standard prognostic factors (14,39,92-94). In the present study, the immunohistochemical scores of PTEN expression were negatively associated with myometrial invasion $(\mathrm{P}=0.002$; $\rho=-0.377$ ). The lower levels of positive PTEN immunostaining scores were associated with deeper myometrial invasion and vice versa. Furthermore, an association was identified between clinical stages and the immunohistochemical scores of PTEN expression $(\mathrm{P}=0.019)$. Patients at clinical stage I had higher positive immunostaining scores, whereas patients at clinical stage II had lower scores. The findings support the hypothesis that lower PTEN expression in endometrial carcinoma occurs in later stages of endometrial carcinogenesis. However, when the sum of stain intensity and scores of PTEN expression were examined, no significant correlations between the age of patients, histologic type, clinical stage, histologic differentiation, myometrial invasion, lymph-vascular space invasion, fallopian and/or ovarian invasion or tumor necrosis were indicated. Daniilidou et al (70) indicated an association between PTEN expression and histologic grade of endometrioid endometrial adenocarcinoma. Notably, the negative expression of PTEN correlated with grade 3, whereas positive PTEN expression correlated with grades I and II (70). In addition, their study revealed an association between PTEN expression and stage of endometrioid endometrial adenocarcinomas (negative expression of PTEN correlated with stages IC and IIC, while positive PTEN expression with stage IB). The findings in the literature regarding the loss PTEN protein expression and clinical outcome in endometrial carcinomas are inconsistent. Some studies have reported more favorable survival $(14,28,29,91,95,96)$, while other studies have indicated less favorable prognosis $(19,90,97,98)$. Terakawa et al (97) suggested that overexpression of PTEN is a significant prognostic indicator of improved overall survival for patients with advanced endometrial carcinoma who undergo postoperative chemotherapy, as PTEN was able to increase the chemosensitivity of neoplastic cells.

In the literature, it is apparent that concomitant genetic alterations may have a prognostic value in endometrial 
carcinoma. It has been indicated that concomitant PI3K-Akt and p53 alterations were associated with poor prognosis (99). In addition, simultaneous activations of p53 and microsatellite instability were strong genetic prognostic factors for disease-free survival (100). Furthermore, Uegaki et al (101) demonstrated that PTEN-positive and phosphorylated-AKT-negative expression is a predictor of survival for patients with advanced endometrial carcinoma. In the present study, an association of the p53 and PTEN co-expression with well-established clinicopathogical factors in patients with endometrial carcinoma was indicated, which opposed the findings of Daniilidou et al (70), in which there was no such correlation. The levels of concomitant p53 and PTEN expression, according to the scores of immunopositive cells, were correlated with the age of patients $(\mathrm{P}=0.008)$ and histologic differentiation $(\mathrm{P}=0.028)$ in the present study. These results suggested that p53 and PTEN co-expression may serve a role in the development of high-grade endometrial carcinoma in older patients. The present findings also suggest the involvement of different molecular pathways in the development of low-grade and high-grade endometrial carcinoma. The findings also suggested a correlation with lymphovascular invasion $(\mathrm{P}=0.084)$, whereas no correlation was identified between the co-expression of p53 and PTEN in endometrial carcinoma (according to the stain intensity or the sum of stain intensity and immunoexpression scores) or clinicopathological characteristics. Therefore, the present study indicated that concomitant p53 and PTEN expression may contribute to the characterization of tumor behavior in endometrial carcinoma. Because the findings of the present study indicated the expression of p53 was positively associated with the levels of PTEN expression in endometrial carcinoma, it was suggested that further molecular studies to estimate and determine the impact of the co-expression of these molecular factors on patient survival of the disease are required.

To conclude, the present results suggest a strong correlation between the expression of p53 and PTEN in endometrial adenocarcinoma, indicating an intrinsic association between the expression of these tumor suppressor genes. In addition, according to the scores of immunopositive cells, which were correlated with the age of patients and the histologic differentiation, concomitant p53 and PTEN expression may contribute to the characterization of tumor behavior in endometrial carcinoma. The findings suggest that combination of p53 and PTEN expression may serve a role in the development of high-grade endometrial carcinoma in older patients. Furthermore, the results imply the involvement of different molecular pathways between the progression of low-grade and high-grade endometrial carcinoma.

\section{Acknowledgements}

The present study was part of a thesis for a Doctor of Philosophy (PhD) in Obstetrics and Gynecology, Medical School, Kapodistrian University of Athens, Greece for Mr. Aggelis Stavropoulos.

\section{Funding}

Not applicable.

\section{Availability of data and materials}

The datasets used and/or analyzed during this study are available from the corresponding author on reasonable request.

\section{Authors' contributions}

All authors were responsible for the conception and design of the present study. TV and AT were responsible for the provision of the study materials. TV, AT, VKV and FNV were responsible for the collection and assembly of the data. AS, MV, TV, VKV, AT, FNV, AN, NK and ACL performed the data analysis and interpretation. AS, MV, TV, VKV, AT, FNV, $\mathrm{AN}, \mathrm{NK}$ and ACL contributed in writing the manuscript. AS, MV, TV, VKV, AT, FNV, AN, NK and ACL read and gave the final approval of the manuscript.

\section{Ethics approval and consent to participate}

The study was approved by the Ethics Committee of Medical School of Kapodistrian University of Athens, Greece. The patient included in the case provided consent for her data to be used in this publication.

\section{Patient consent for publication}

All the patients included in this study at the time of data collection provided consent for their data to be used in this publication.

\section{Competing interests}

The authors declare that they have no competing interests.

\section{References}

1. Liu FS: Molecular carcinogenesis of endometrial cancer. Taiwan J Obstet Gynecol 46: 26-32, 2007.

2. Sasnauskienė A, Jonušienė V, Krikštaponienė A, Butkytė S Dabkevičienė D, Kanopienė D, Kazbarienė B and Didžiapetrienė J: NOTCH1, NOTCH3, NOTCH4, and JAG2 protein levels in human endometrial cancer. Medicina (Kaunas) 50: 14-18, 2014.

3. Elbasateeny SS, Salem AA, Abdelsalam WA and Salem R: Immunohistochemical expression of cancer stem cell related markers CD44 and CD133 in endometrial cancer. Pathol Res Pract 212: 10-16, 2016.

4. Li Y, Zhang X, Ge J, Liu X, Xu S, Zhu Z, Fang G, Liu J, Zhang H and Sun X: Can Nup88 expression be associated with atypical endometrial hyperplasia and endometrial cancer? A preliminary study. Pathol Res Pract 212: 274-278, 2016.

5. Agopianz M,Forgez P, Casse JM,Lacomme S, Charra-Brunaud C, Clerc-Urmès I, Morel O, Bonnet C, Guéant JL, Vignaud JM, et al: Expression of neurotensin receptor 1 in endometrial adenocarcinoma is correlated with histological grade and clinical outcome. Virchows Arch 471: 521-530, 2017.

6. Khabaz MN, Abdelrahman AS, Butt NS, Al-Maghrabi B and Al-Maghrabi J: Cyclin D1 is significantly associated with stage of tumor and predicts poor survival in endometrial carcinoma patients. Ann Diagn Pathol 30: 47-51, 2017.

7. Mittal P, Klingler-Hoffmann M, Arentz G, Winderbaum L, Kaur G, Anderson L, Scurry J, Leung Y, Stewart CJ, Carter J, et al: Annexin A2 and alpha actinin 4 expression correlates with metastatic potential of primary endometrial cancer. Biochim Biophys Acta Proteins Proteom 1865: 846-857, 2017.

8. Qiu M, Bao W, Wang J, Yang T, He X, Liao Y and Wan X: FOXA1 promotes tumor cell proliferation through AR involving the Notch pathway in endometrial cancer. BMC Cancer 14: 78, 2014. 
9. Gu X, Liu Q, Yang N, Shen JF, Zhang XG, Cao F and Ding HZ: Clinicopathological significance of increased ZIC1 expression in human endometrial cancer. J Huazhong Univ Sci Technolog Med Sci 35: 898-903, 2015

10. Bansal N, Yendluri V and Wenham RM: The molecular biology of endometrial cancers and the implications for pathogenesis, classification, and targeted therapies. Cancer Control 16: 8-13, 2009.

11. Dohi S, Ohno S, Ohno Y, Kyo S, Soma G, Sugiyama H and Inoue M: WT1 expression correlates with angiogenesis in endometrial cancer tissue. Anticancer Res 30: 3187-3192, 2010.

12. Stambolic V, Suzuki A, de la Pompa JL, Brothers GM, Mirtsos C, Sasaki T, Ruland J, Penninger JM, Siderovski DP and Mak TW: Negative regulation of PKB/Akt-dependent cell survival by the tumor suppressor PTEN. Cell 95: 29-39, 1998.

13. Scully MM, Palacios-Helgeson LK, Wah LS and Jackson TA: Rapid estrogen signaling negatively regulates PTEN activity through phosphorylation in endometrial cancer cells. Horm Cancer 5: 218-231, 2014.

14. Erkanli S, Kayaselcuk F, Kuscu E, Bagis T, Bolat F, Haberal A and Demirhan B: Expression of survivin, PTEN and p27 in normal, hyperplastic, and carcinomatous endometrium. Int J Gynecol Cancer 16: 1412-1418, 2006.

15. Konopka B, Paszko Z, Janiec-Jankowska A and Goluda M: Assessment of the quality and frequency of mutations occurrence in PTEN gene in endometrial carcinomas and hyperplasias. Cancer Lett 178: 43-51, 2002.

16. Kimura F, Watanabe J,Hata H,Fujisawa T, Kamata Y, Nishimura Y, Jobo T and Kuramoto H: PTEN immunohistochemical expression is suppressed in G1 endometrioid adenocarcinoma of the uterine corpus. J Cancer Res Clin Oncol 130: 161-168, 2004

17. Machwinnie N and Monaghan H: The use of P53, PTEN, and C-erbB-2 to differentiate uterine serous papillary carcinoma from endometrioid endometrial carcinoma. Int J Gynecol Cancer 14: 938-946, 2004

18. Kapucuoglu N, Aktepe F, Kaya H, Bircan S, Karahan N and Ciriş M: Immunohistochemical expression of PTEN in normal, hyperplastic and malignant endometrium and its correlation with hormone receptors, bcl-2, bax, and apoptotic index. Pathol Res Pract 203: 153-162, 2007.

19. Kanamori Y, Kigawa J, Itamochi H, Sultana H, Suzuki M, Ohwada M, Kamura T, Sugiyama T, Kikuchi Y, Kita T, et al: PTEN expression is associated with prognosis for patients with advanced endometrial carcinoma undergoing postoperative chemotherapy. Int J Cancer 100: 686-689, 2002.

20. Mayo LD, Dixon JE, Durden DL, Tonks NK and Donner DB: PTEN protects p53 from Mdm2 and sensitizes cancer cells to chemotherapy. J Biol Chem 277: 5484-5489, 2002.

21. Garg K, Broaddus RR, Soslow RA, Urbauer DL, Levine DA and Djordjevic B: Pathologic scoring of PTEN immunohistochemistry in endometrial carcinoma is highly reproducible. Int $\mathbf{J}$ Gynecol Pathol 31: 48-56, 2012.

22. Jeczen R, Skomra D, Cybulski M, Scheider-Stock R, Szewczuk W, Roessner A, Rechberger T and Semczuk A: P53/MDM2 overexpression in metastatic endometrial cancer: correlation with clinicopathological features and patient outcome. Clin Exp Metastasis 24: 503-511, 2007.

23. Pallares J, Bussaglia E, Martínez-Guitarte JL, Dolcet X, Llobet D, Rue M, Sanchez-Verde L, Palacios J, Prat J and Matias-Guiu X: Immunohistochemical analysis of PTEN in endometrial carcinoma: A tissue microarray study with a comparison of four commercial antibodies in correlation with molecular abnormalities. Mod Pathol 18: 719-727, 2005.

24. Westin SN, Ju Z, Broaddus RR, Krakstad C, Li J, Pal N, Lu KH, Coleman RL, Hennessy BT, Klempner SJ, et al: PTEN loss is a context-dependent outcome determinant in obese and non-obese endometrioid endometrial cancer patients. Mol Oncol 9: 1694-1703, 2015.

25. Chen J, Li S, Yang Z, Lu G and Hu H: Correlation between NDRG1 and PTEN expression in endometrial carcinoma. Cancer Sci 99: 706-710, 2008 .

26. Lacey JV Jr, Mutter GL, Ronnett BM, Ioffe OB, Duggan MA, Rush BB, Glass AG, Richesson DA, Chatterjee N, Langholz B, Sherman ME: PTEN expression in endometrial biopsies as a marker of progression to endometrial carcinoma. Cancer Res 68 6014-6020, 2008

27. Merritt MA and Cramer DW: Molecular pathogenesis of endometrial and ovarian cancer. Cancer Biomark 9: 287-305, 2010

28. Fadare $\mathrm{O}$ and Parksh V: p53 aberrations in low grade endometrioid carcinoma of the endometrium with nodal metastases: Possible insights on pathogenesis discerned from immunohistochemistry. Diagn Pathol 12: 81, 2017.
29. Jiang Z, Xu W, Dan G, Liu Y and Xiong J: P53 and murine double minute 2 (MDM2) expression changes and significance in different types of endometrial lesions. Med Sci Monit 22: 4786-4793, 2016

30. Kounelis S, Kapranos N, Kouri E, Coppola D, Papadaki H and Jones MW: Immunohistochemical profile of endometrial adenocarcinoma: A study of 61 cases and review of the literature. Mod Pathol 13: 379-388, 2000.

31. Mazurek A, Kuć P, Mazurek-Wadołkowska E and Laudański T: A role of thymidine phosphorylase and P53 tissue protein expression in biology of endometrial cancer. Neoplasma 55: 261-265, 2008

32. Oda K, Okada J, Timmerman L, Rodriguez-Viciana P, Stokoe D, Shoji K, Taketani Y, Kuramoto H, Knight ZA, Shokat KM and McCormick F: PIK3CA cooperates with other phosphatidylinositol 3'-kinase pathway mutations to effect oncogenic transformation. Cancer Res 68: 8127-8136, 2008.

33. Li SF, Shiozawa T, Nakayama K, Nikaido T and Fujii S: Stepwise abnormality of sex steroid hormone receptors, tumor suppressor gene products (p53 and $\mathrm{Rb}$ ), and cyclin $\mathrm{E}$ in uterine endometrioid carcinoma. Cancer 77: 321-329, 1996.

34. Ozkara SK and Corakci A: Significantly decreased P27 expression in endometrial carcinoma compared to complex hyperplasia with atypia (correlation with p53 expression). Pathol Oncol Res 10: 89-97, 2004

35. Edmondson RJ, Crosbie EJ, Nickkho-Amiry M, Kaufmann A, Stelloo E, Nijman HW, Leary A, Auguste A, Mileshkin L, Pollock $\mathrm{P}$, et al: Markers of the p53 pathway further refine molecular profiling in high-risk endometrial cancer: A TransPORTEC initiative. Gynecol Oncol 146: 327-333, 2017.

36. Suzuki C, Matsumoto T, Sonoue H, Arakawa A, Furugen Y and Kinoshita K: Prognostic significance of the infiltrative pattern invasion in endometrioid adenocarcinoma of the endometrium. Pathol Int 53: 495-500, 2003

37. Ambros RA, Ross JS, Kallakury BV, Malfetano J, Kim Y, Hwang J, Breese K and Figge J: p53 gene status in endometrial carcinomas showing diffuse positivity for $\mathrm{p} 53$ protein by immunohistochemical analysis. Mod Pathol 8: 441-445, 1995.

38. Ambros RA, Sheehan CE, Kallakury BV, Ross JS, Malfetano J, Paunovich E and Figge J: MDM2 and p53 protein expression in the histologic subtypes of endometrial carcinoma. Mod Pathol 9: $1165-1169,1996$.

39. Tashiro H, Blazes MS, Wu R, Cho KR, Bose S, Wang SI, Li J, Parsons R and Ellenson LH: Mutations in PTEN are frequent in endometrial carcinoma but rare in other common gynecological malignancies. Cancer Res 57: 3935-3940, 1997.

40. Sakuragi N, Hirai A, Tada M, Yamada H, Yamamoto R, Fujimoto S and Moriuchi T: Dominant-negative mutation of p53 tumor suppressor gene in endometrial carcinoma. Gynecol Oncol 83: 485-490, 2001.

41. Appel ML, Edelweiss MI, Fleck J, Rivero LF, Rivoire WA, Mônego HI and Dos Reis R: P53 and BCL-2 as prognostic markers in endometrial carcinoma. Pathol Oncol Res 14: 23-30, 2008.

42. Athanassiadou P, Athanassiades P, Grapsa D, Gonidi M, Athanassiadou AM, Stamati PN and Patsouris E: The prognostic value of PTEN, p53, and beta-catenin in endometrial carcinoma: A prospective immunocytochemical study. Int J Gynecol Cancer 17: 697-704, 2007.

43. Ellenson LH: Early molecular changes in endometrial cancer. Int J Gynecol Cancer 15: 399-400, 2005.

44. Lax SF: Molecular genetic pathways in various types of endometrial carcinoma: From a phenotypical to a molecular-based classification. Virchows Arch 444: 213-223, 2004.

45. Darvishian F, Hummer AJ, Thaler HT, Bhargava R, Linkov I, Asher M and Soslow RA: Serous endometrial cancers that mimic endometrioid adenocarcinomas: A clinicopathologic and immunohistochemical study of a group of problematic cases. Am J Surg Pathol 28: 1568-1578, 2004.

46. Cancer Genome Atlas Research Network, Kandoth C, Schultz N, Cherniack AD, Akbani R, Liu Y, Shen H, Robertson AG, Pashtan I, Shen R, et al: Integrated genomic characterization of endometrial carcinoma. Nature 497: 67-73, 2013.

47. Fadare $\mathrm{O}$ and Zheng W: Insights into endometrial serous carcinogenesis and progression. Int J Clin Exp Pathol 2: 411-432, 2009.

48. Fadare O, Gwin K, Desouki MM, Crispens MA, Jones HW III, Khabele D, Liang SX, Zheng W, Mohammed K, Hecht JL and Parkash V: The clinicopathologic significance of p53 and BAF-250a (ARID1A) expression in clear cell carcinoma of the endometrium. Mod Pathol 26: 1101-1110, 2013. 
49. Ramalingam P, Masand RP, Eucher ED and Malpica A: Undifferentiated carcinoma of the endometrium: An expanded immunohistochemical analysis including PAX-8 and basal-like carcinoma surrogate markers. Int J Gynecol Pathol 35: 410-418, 2016.

50. Hoang LN, Lee YS, Karnezis AN, Tessier-Cloutier B, Almandani N, Coatham M, Gilks CB, Soslow RA, Stewart CJ, Köbel $\mathrm{M}$ and Lee $\mathrm{CH}$ : Immunophenotypic features of dedifferentiated endometrial carcinoma-insights from BRG1/INI1-deficient tumours. Histopathology 69: 560-569, 2016.

51. Lopez-Garcia MA and Palacios J: Pathologic and molecular features of uterine carcinosarcomas. Semin Diagn Pathol 27: 274-286, 2010

52. Cherniack AD, Shen H, Walter V, Stewart C, Murray BA, Bowlby R, Hu X, Ling S, Soslow RA, Broaddus RR, et al: Integrated molecular characterization of uterine carcinosarcoma. Cancer Cell 31: 411-423, 2017.

53. Alvarez T, Miller E, Duska L and Oliva E: Molecular profile of grade 3 endometrioid endometrial carcinoma: Is it a type I or type II endometrial carcinoma? Am J Surg Pathol 36: 753-761, 2012.

54. Sherman ME, Bur ME and Kurman RJ: p53 in endometrial cancer and its putative precursors: Evidence for diverse pathways of tumorigenesis. Hum Pathol 26: 1268-1274, 1995.

55. Moll MU, Chalas E, Auguste M, Meaney D and Chumas J: Uterine papillary serous carcinoma evolves via a p53-driven pathway. Hum Pathol 27: 1295-1300, 1996.

56. Zheng W, Cao P, Zheng M, Kramer EE and Godwin TA: p53 overexpression and bcl-2 persistence in endometrial carcinoma: Comparison of papillary serous and endometrioid subtypes. Gynecol Oncol 61: 167-174, 1996.

57. Bur ME, Perlman C, Edelmann BS, Fey E and Rose PG: p53 expression in neoplasms of the uterine corpus. Am J Clin Pathol 98: 81-87, 1992.

58. Inoue M, Fujita M, Enomoto $\mathrm{T}$, Morimoto $\mathrm{H}$, Monden $\mathrm{T}$, Shinano $\mathrm{T}$ and Tanizawa $\mathrm{O}$ : Immunohistochemical analysis of p53 in gynecologic tumors. Am J Clin Pathol 102: 665-670, 1994

59. Prat J, Oliva E, Lerma E, Vaquero M and Matías-Guiu X: Uterine papillary serous adenocarcinoma. A 10-case study of p53 and c-erbB-2 expression and DNA content. Cancer 74: 1778-1783, 1994.

60. Reinartz JS, George E, Lindgren BR and Niehans GA: Expression of p53, transforming growth factor alpha, epidermal grow th factor receptor, and c-erbB-2 in endometrial carcinoma and correlation with survival and known predictors of survival. Hum Pathol 25: 1075-1083, 1994.

61. Khalifa MA, Mannel RS, Haraway SD, Walker J and Min KW: Expression of EGFR,HER-2/neu,P53, and PCNA in endometrioid, serous papillary, and clear cell endometrial adenocarcinomas. Gynecol Oncol 53: 84-92, 1994.

62. King SA, Adas AA, LiVolsi VA, Takahashi H, Behbakht K McGovern P, Benjamin I, Rubin SC and Boyd J: Expression and mutation analysis of the p53 gene in uterine papillary serous carcinoma. Cancer 75: 2700-2705, 1995.

63. Tashiro H, Isacson C, Levine R, Kurman RJ, Cho KR and Hedrick L: p53 gene mutations are common in uterine serous carcinoma and occur early in their pathogenesis. Am J Pathol 150: 177-185, 1997.

64. Soslow RA, Shen PU, Chung MH and Isacson C: Distinctive p53 and $\mathrm{mdm} 2$ immunohistochemical expression profiles suggest different pathogenetic pathways in poorly differentiated endometrial carcinoma. Int J Gynecol Pathol 17: 129-134, 1998

65. Garcia-Dios DA, Lambrechts D, Coenegrachts L, Vandenput I, Capoen A, Webb PM, Ferguson K; ANECS, Akslen LA, Claes B, et al: High-throughput interrogation of PIK3CA, PTEN, KRAS, FBXW7 and TP53 mutations in primary endometrial carcinoma. Gynecol Oncol 128: 327-334, 2013.

66. Seeger A, Kölbl H, Petry IB, Gebhard S, Battista MJ, Böhm D and Steiner E: p53 is correlated with low BMI negative progesterone receptor status and recurring disease in patients with endometrial cancer. Gynecol Oncol 125: 200-207, 2012.

67. Urabe R, Hachisuga T, Kurita T, Kagami S, Kawagoe T, Matsuura Y and Shimajiri S: Prognostic significance of overexpression of p53 in uterine endometrioid adenocarcinomas with an analysis of nuclear grade. J Obstet Gynaecol Res 40: 812-819, 2014.

68. Lee EJ, Kim TJ, Kim DS, Choi CH, Lee JW, Lee JH, Bae DS and Kim BG: p53 alteration independently predicts poor outcomes in patients with endometrial cancer: A clinicopathologic study of 131 cases and literature review. Gynecol Oncol 116: 533-538, 2010
69. Kurnit KC, Kim GN, Fellman BM, Urbauer DL, Mills GB, Zhang W and Broaddus RR: CTNNB1 (beta-catenin) mutation identifies low grade, early stage endometrial cancer patients at increased risk of recurrence. Mod Pathol 30: 1032-1041, 2017.

70. Daniilidou K, Frangou-Plemenou M, Grammatikakis J, Grigoriou O, Vitoratos N and Kondi-Pafiti A: Prognostic significance and diagnostic value of PTEN and p53 expression in endometrial carcinoma. A retrospective clinicopathological and immunohistochemical study. J BUON 18: 195-201, 2013.

71. Ohkouchi T, Sakuragi N, Watari H, Nomura E, Todo Y, Yamada H and Fujimoto S: Prognostic significance of Bcl-2, p53 overexpression, and lymph node metastasis in surgically staged endometrial carcinoma. Am J Obstet Gynecol 187: 353-359, 2002.

72. Erdem O, Erdem M, Dursun A, Akyol G and Erdem A: Angiogenesis, $\mathrm{p} 53$, and bcl-2 expression as prognostic indicators in endometrial cancer: Comparison with traditional clinicopathologic variables. Int J Gynecol Pathol 22: 254-260, 2003.

73. Hirschowitz L, Ganesan R and McCluggage WG: WT1, p53 and hormone receptor expression in uterine serous carcinoma. Histopathology 55: 478-482, 2009

74. Mariani A, Sebo TJ, Webb MJ, Riehle D, Katzmann JA, Keeney GL, Roche PC, Lesnick TG and Podratz KC: Molecular and histopathologic predictors of distant failure in endometrial cancer. Cancer Detect Prev 27: 434-441, 2003.

75. Ito K, Watanabe K, Nasim S, Sasano H, Sato S, Yajima A, Silverberg SG and Garrett CT: Prognostic significance of p53 overexpression in endometrial cancer. Cancer Res 54: 4667-4670, 1994.

76. Alkushi A, Lim P, Coldman A, Huntsman D, Miller D and Gilks CB: Interpretation of p53 immunoreactivity in endometrial carcinoma: Establishing a clinically relevant cut-off level. Int J Gynecol Pathol 23: 129-137, 2004

77. Hamel NW, Sebo TJ, Wilson TO, Keeney GL, Roche PC, Suman VJ, Hu TC and Podratz KC: Prognostic value of p53 and proliferating cell nuclear antigen expression in endometrial carcinoma. Gynecol Oncol 62: 192-198, 1996.

78. Bancher-Todesca D, Gitsch G, Williams KE, Kohlberger P, Neunteufel W, Obermair A, Heinze G, Breitenecker G and Hacker NF: p53 protein overexpression: A strong prognostic factor in uterine papillary serous carcinoma. Gynecol Oncol 71: 59-63, 1998.

79. Geisler JP, Geisler HE, Wiemann MC, Zhou Z, Miller GA and Crabtree W: p53 expression as a prognostic indicator of 5-year survival in endometrial cancer. Gynecol Oncol 74: 468-471, 1999.

80. Oreskovic S, Babic D, Kalafatic D, Barisic D and BeketicOreskovic L: A significance of immunohistochemical determination of steroid receptors, cell proliferation factor Ki-67 and protein p53 in endometrial carcinoma. Gynecol Oncol 93: 34-40, 2004.

81. Osmanağaoğlu MA, Kadioğlu S, Osmanağaoğlu S, Bozkaya $\mathrm{H}$, Reis A and Tekelioğlu Y: The relationship between mutant p53 gene, DNA contents and conventional clinicopathological prognostic variables in cases with endometrial carcinoma. Eur J Gynaecol Oncol 26: 64-70, 2005

82. Soong R, Knowles S, Williams KE, Hammond IG, Wysocki SJ and Iacopetta BJ: Overexpression of p53 protein is an independent prognostic indicator in human endometrial carcinoma. Br J Cancer 74: 562-567, 1996

83. Jeon YT, Kang S, Kang DH, Yoo KY, Park IA, Bang YJ, Kim JW, Park NH, Kang SB, Lee HP and Song YS: Cyclooxygenase-2 and p53 expression in endometrial cancer. Cancer Epidemiol Biomarkers Prev 13: 1538-1542, 2004.

84. Risinger JI, Hayes K, Maxwell GL, Carney ME, Dodge RK, Barrett JC and Berchuck A: PTEN Mutation in endometrial cancers is associated with favorable clinical and pathologic characteristics. Clin Cancer Res 4: 3005-3010, 1998.

85. Maxwell GL, Risinger JI, Hayes KA, Alvarez AA, Dodge RK, Barrett JC and Berchuck A: Racial disparity in the frequency of PTEN mutations, but not microsatellite instability, in advanced endometrial cancers. Clin Cancer Res 6: 2999-3005, 2000.

86. Levine RL, Cargile CB, Blazes MS, van Rees B, Kurman RJ and Ellenson LH: PTEN mutations and microsatellite instability in complex atypical hyperplasia, a precursor lesion to uterine endometrioid carcinoma. Cancer Res 58: 3254-3258, 1998.

87. Yoshinaga K, Sasano H, Furukawa T, Yamakawa H, Yuki M, Sato S, Yajima A and Horii A: The PTEN, BAX, and IGFIIR genes are mutated in endometrial atypical hyperplasia. Jpn J Cancer Res 89: 985-990, 1998.

88. Mutter GL, Lin MC, Fitzgerald JT, Kum JB, Baak JP, Lees JA, Weng LP and Eng C: Altered PTEN expression as a diagnostic marker for the earliest endometrial precancers. J Natl Cancer Inst 92: 924-930, 2000 
89. Peiffer SL, Herzog TJ, Tribune DJ, Mutch DG, Gersell DJ and Goodfellow PJ: Allelic loss of sequences from the long arm of chromosome 10 and replication errors in endometrial cancers. Cancer Res 55: 1922-1926, 1995.

90. Nagase S, Sato S, Tezuka F, Wada Y, Yajima A and Horii A: Deletion mapping on chromosome 10q25-q26 in human endometrial cancer. Br J Cancer 74: 1979-1983, 1996.

91. Akiyama-Abe A, Minaguchi T, Nakamura Y, Michikami H, Shikama A, Nakao S, Sakurai M, Ochi H, Onuki M, Matsumoto K, et al: Loss of PTEN expression is an independent predictor of favourable survival in endometrial carcinomas. Br J Cancer 109: 1703-1710, 2013.

92.Bussaglia E, del Rio E, Matias-Guiu X and Prat J: PTEN mutations in endometrial carcinomas: A molecular and clinicopathologic analysis of 38 cases. Hum Pathol 31: 312-317, 2000.

93. Kanamori Y, Kigawa J, Itamochi H, Shimada M, Takahashi M, Kamazawa S, Sato S, Akeshima R and Terakawa N: Correlation between loss of PTEN expression and Akt phosphorylation in endometrial carcinoma. Clin Cancer Res 7: 892-895, 2001.

94. Minaguchi T, Yoshikawa H, Oda K, Ishino T, Yasugi T, Onda T, Nakagawa S, Matsumoto K, Kawana K and Taketani Y: PTEN mutation located only outside exons 5, 6, and 7 is an independent predictor of favorable survival in endometrial carcinomas. Clin Cancer Res 7: 2636-2642, 2001

95. Dellas A, Jundt G, Sartorius G, Schneider M and Moch H: Combined PTEN and p27kip1 protein expression patterns are associated with obesity and prognosis in endometrial carcinomas. Clin Cancer Res 15: 2456-2462, 2009.

96. Mackay HJ, Gallinger S, Tsao MS, McLachlin CM, Tu D, Keiser K, Eisenhauer EA and Oza AM: Prognostic value of microsatellite instability (MSI) and PTEN expression in women with endometrial cancer: Results from studies of the NCIC Clinical Trials Group (NCIC CTG). Eur J Cancer 46: 1365-1373, 2010.
97. Terakawa N, Kanomori Y and Yoshida S: Loss of PTEN expression followed by Akt phosphorylation is poor prognostic factor for patients with endometrial cancer. Endocr Relat Cancer 10: 203-208, 2003.

98. Salvesen HB, Stefansson I, Kalvenes MB, Das S and Akslen LA Loss of PTEN expression is associated with metastatic disease in patients with endometrial carcinoma. Cancer 94: 2185-2191, 2002.

99. Catasus L, Gallardo A, Cuatrecasas M and Prat J: Concomitant PI3K-AKT and $\mathrm{p} 53$ alterations in endometrial carcinomas are associated with poor prognosis. Mod Pathol 22: 522-529, 2009.

100. Nout RA, Bosse T, Creutzberg CL, Jürgenliemk-Schulz IM, Jobsen JJ, Lutgens LC, van der Steen-Banasik EM, van Eijk R, Ter Haar NT and Smit VT: Improved risk assessment of endometrial cancer by combined analysis of MSI, PI3K-AKT, Wnt/ $\beta$-catenin and P53 pathway activation. Gynecol Oncol 126 : 466-473, 2012.

101. Uegaki K, Kanamori Y, Kigawa J, Kawaguchi W, Kaneko R, Naniwa J, Takahashi M, Shimada M, Oishi T, Itamochi $\mathrm{H}$ and Terakawa N: PTEN-positive and phosphorylated-Akt-negative expression is a predictor of survival for patients with advanced endometrial carcinoma. Oncol Rep 14: 389-392, 2005.

This work is licensed under a Creative Commons Attribution-NonCommercial-NoDerivatives 4.0 International (CC BY-NC-ND 4.0) License. 